\title{
Estigmas, guetos e "gentrificação": a segregação homossexual em Brasília
}

Cristina Monteiro de Queiroz

Curso: Mestrado em Sociologia

Data da defesa: 30 de junho de 2008

Orientador: Prof. Dr. Brasilmar Ferreira Nunes

\section{Resumo}

A pesquisa tem como objetivo entender a segregação homossexual nos espaços de lazer na cidade de Brasília, abordando os conceitos de segregação espacial - especialmente os de guetos e "gentrificação" - e a noção de estigma. A intenção é compreender como os próprios homossexuais entendem e percebem os lugares que freqüentam. Para tanto, foram estabelecidas três hipóteses na pesquisa: i) hipótese do gueto, que afirma que a segregação social nas metrópoles - neste caso, Brasília - produz uma articulação entre espaço social e espaço físico que qualifica certas áreas da cidade como guetos, não como áreas "gentrificadas"; ii) hipótese do estigma, que infere que a imposição ou voluntarismo de certos grupos a guetos está intimamente ligada ao tipo de estigma (desacreditado ou desacreditável) sofrido pelos integrantes desses mesmos grupos; e iii) hipótese do voluntarismo, que classifica os homossexuais como desacreditáveis e, portanto, a sua segregação a certos tipos de espaços é tida como voluntária por eles mesmos. Durante a pesquisa de campo realizada em três espaços da cidade reconhecidos por sua freqüência homossexual - bar Barulho, bar Beirute e Café Savana -, verificou-se que esses espaços freqüentados por homossexuais na cidade se aproximam mais do conceito de gueto do que de áreas gentrificadas. Da mesma forma, também foi verificado que a 
maioria dos entrevistados se posiciona como desacreditável, uma vez que muitos deles pontuam a existência do preconceito como uma conseqüência de atos individuais e, portanto, passíveis de serem encobertos. Já a hipótese do estigma foi evidenciada a partir da contraposição dos estudos de Louis Wirth e Loic Wacquant acerca do gueto judeu e negro, respectivamente. Constatou-se, ainda, durante o estudo, como Brasília - como palco da pesquisa exerce influência sobre os comportamentos sociais em razão de sua arquitetura particular, evidenciando o reflexo das relações espaciais da cidade nas relações sociais de seus habitantes.

Palavras-chave: sociologia urbana; segregação social; guetos; "gentrificação"; estigma; homossexualidade; espaços urbanos. 